\title{
AS ÁREAS DE PRESERVAÇÃo PERMAMENTE E A LIMITAÇÃO AO USO DA PROPRIEDADE
}

THE AREAS OF PERMANENTLY PRESERVATION AND THE LIMITATION ON THE USE OF

THE PROPERTY

Bruno de Abreu SOARES ${ }^{1}$

ISSUE DOI: $10.21207 / 2675-0104.2017 .658$

\begin{abstract}
RESUMO
O presente trabalho tem por objetivo apresentar a relação entre direito de propriedade e função socioambiental, que fundamenta a imposição pelo Poder Público de limitações administrativas à propriedade privada para a preservação, conservação e recomposição nas áreas de preservação permanente, onde por imposição legal não é admitida a exploração do solo ou a supressão da cobertura vegetal, tanto em espaços rurais como urbanos. Apesar do direito à propriedade estar sob a proteção constitucional como um dos pressupostos da economia, sobrepõe-se a este os princípios da função social da propriedade e a proteção ao meio ambiente ecologicamente equilibrado, em benefício de toda a coletividade, que permite ao Estado intervir na regulação do direito de propriedade, da exploração econômica em face da função social ambiental conforme o Código Florestal regulamenta. Este estudo verificou que mesmo com os benefícios que o proprietário pode gozar, como o pagamento a serviços ambientais de conservação, ou obter facilitação de crédito agrícola e, ainda dedução das áreas do cálculo do Imposto sobre a Propriedade Territorial Rural, os ônus e transtornos ao proprietário rural devido a restrições que estas áreas impostas pelo Poder Público prejudicam a rentabilidade econômica dos mesmos, em especial o pequeno produtor rural. A presente pesquisa utiliza o método dedutivo, a partir do qual desenvolve um raciocínio lógico, partindo de uma premissa geral, uma verdade estabelecida, finalizando em uma situação particularizada. Os procedimentos metodológicos usados foram o bibliográfico e o procedimento exegético, a fim de se compreender o verdadeiro sentido e alcance da norma jurídica, buscando atingir a real intenção do legislador, assim como o procedimento sistemático, analisando a norma a partir do sistema que está inserida.
\end{abstract}

\footnotetext{
${ }^{1}$ Discente da Faculdade de Direito de Franca/SP. Bolsista do Programa Interno de Iniciação Cientítica (PIBIC 2016-2017).
} 
Palavras-chave: Áreas de Preservação Permanente. Limitações. Função socioambiental. Propriedade.

\begin{abstract}
The present paper aims to present the relationship between property rights and socioenvironmental function, which is based on the imposition by the Government of administrative limitations on private property for preservation, conservation and restoration in the areas of permanent preservation, where by legal imposition it is not allowed the exploitation of the soil or the suppression of the vegetal cover, in both rural and urban spaces. Although the right to property is under constitutional protection as one of the presuppositions of the economy, it overlaps with it the principles of the social function of property and the protection of the ecologically balanced environment, for the benefit of the whole community, which allows the State to intervene in the regulation of property rights, economic exploitation in the face of social environmental function as regulated by the Forest Code. This study verified that even with the benefits that the owner can enjoy such as the payment to environmental conservation services, or to obtain agricultural credit facilitation and, still deduction of the areas of the calculation of the Tax on Rural Territorial Property, the onus and inconvenience to the owner rural areas due to restrictions that these areas imposed by the Public Power damage the economic profitability of the same, especially the small rural producer. the present research uses the deductive method, from which it develops a logical reasoning, starting from a general premise, an established truth, finalizing in a particularized situation. The methodological procedures used were the bibliographic, exegetical procedure, in order to understand the true meaning and scope of the legal norm, seeking to achieve the real intention of the legislator, as well as the systematic procedure, analyzing the norm from the system that is inserted.
\end{abstract}

Keywords: Permanent Preservation Areas. Limitations. Socio-environmental function. Property

A preocupação com a preservação ao meio ambiente é relativamente recente, visto que apenas surgiu a partir do momento em que se sentiram as consequências nocivas das atividades humanas advindas da poluição e da degradação ambiental em diversas formas, já na segunda metade do Século XX.

\title{
2 DIREITO AMBIENTAL CONSTITUCIONAL
}

Com a preocupação em se proteger ao máximo o meio ambiente, foi construído no Brasil um conjunto de normas que disciplinam como devem ser realizadas as atividades humanas minimizando qualquer tipo de impacto, denominado Direito Ambiental.

O Direito Ambiental, assim, constitui o conjunto de regras jurídicas de direito público que norteiam as atividades humanas, ora impondo limites, ora induzindo comportamentos por meio de instru- 
mentos econômicos, com o objetivo de garantir que essas atividades não causem danos ao meio ambiente, impondo-se a responsabilização e as consequentes sanções aos transgressores dessas normas. (GRANZIERA, Maria Luiza. Direito Ambiental. $2^{\mathrm{a}}$ edição. Editora Atlas. São Paulo: 2011. p. 06).

Apesar de estar classificado como um direito público, o direito ambiental se relaciona com o direito privado, em especial no que tange à propriedade, aos bens e à responsabilidade.

Logo, por ser irrefutável o interesse na conservação do dos recursos naturais, o direito ambiental trouxe a regulamentação do seu uso de maneira sustentável, por meio das normas e princípios. Dessa forma, José Afonso da Silva, menciona que o meio ambiente equilibrado é de interesse público que abrange todos e não como bem público ou particular. (SILVA, José. Afonso da. Direito Ambiental Constitucional, $2^{\mathrm{a}}$ ed., São Paulo: Malheiros, 1997, p.36).

Observa-se que a Constituição Federal de 1988 não apenas instituiu a presença de um bem ambientalmente protegido, de uso comum da sociedade, mas determinou que este mesmo bem devesse ser protegido pela coletividade e, pelo Poder Público, já que todos tem o direito de ter um meio ambiente equilibrado, destinado a manter a salutar qualidade de vida da população.

Ao tratar da definição de meio ambiente, Hugo Nigro Mazzilli destaca que:

O conceito legal e doutrinário é tão amplo que nos autoriza a considerar de forma praticamente ilimitada a possibilidade de defesa da flora, da fauna, das águas, do solo, do subsolo, do ar, ou seja, de todas as formas de vida e de todos os recursos naturais, como base na conjugação do art. 225 da Constituição com as Leis ns. 6.938/81 e 7.347/85. Estão assim alcançadas todas as formas de vida, não só aquelas da biota (conjunto de todos os seres vivos de uma região) como da biodiversidade (conjunto de todas as espécies de seres vivos existentes na biosfera, ou seja, todas as formas de vida em geral do planeta), e até mesmo está protegido o meio que as abriga ou lhes permite a subsistência. (MAZZILLI, Hugo Nigro. A Defesa dos Interesses Difusos em Juízo. 18. ed. São Paulo: Saraiva, 2005. P. 142-145).

O caráter difuso do direito ambiental acentua-se, quando o referido capítulo constitucional diz que é dever da coletividade e do poder público defender e preservar o meio ambiente, respaldado em uma relação de valores constitucional de solidariedade. A inclusão de um direito ao meio ambiente ecologicamente equilibrado, na Constituição Federal de 1988, 
determina que as normas infraconstitucionais sejam interpretadas e elaboradas em conformidade ao disposto no texto constitucional; as que se encontrarem em desacordo deverão ter decretadas a sua inconstitucionalidade, tanto do texto legal quanto da interpretação a ela conferida. A superioridade jurídica, portanto, tem poder para realizar o controle de constitucionalidade das normas infraconstitucionais ambientais e, também, de suas interpretações.

\title{
2.1 DIMENSÃO DO DIREITO FUNDAMENTAL EM REFERÊNCIA AO MEIO AMBIENTE
}

Direitos fundamentais podem ser entendidos como aqueles inerentes à vida humana, em todos os seus aspectos, sem os quais os indivíduos não teriam a possibilidade de gozar e usufruir da vida com dignidade, saúde, bem-estar, entre outros.

\begin{abstract}
São todas aquelas posições jurídicas favoráveis às pessoas que explicitam, direta ou indiretamente, o princípio da dignidade humana, que se encontram reconhecidas no teto da Constituição formal (fundamentalidade formal) ou que, por seu conteúdo e importância, são admitidas e equiparadas, pela própria Constituição, aos direitos que esta formalmente reconhece, embora dela não façam parte (fundamentalidade material). (CUNHA JÚNIOR, Dirley da. Curso de Direito Constitucional. 2. ed. Salvador: Juspodivm, 2008. p. 573.).
\end{abstract}

A proteção do meio ambiente como fundamental o torna mais amplo e efetivo, visando à garantia de conservação no presente momento, assim como para o futuro.

Visando a evolução histórica, os direitos fundamentais são classificados em três gerações ou dimensões. Nota-se que tal nomenclatura é discutida doutrinariamente, mas não será objeto do presente trabalho.

$\mathrm{Na}$ primeira geração, encontram-se os direitos de liberdade, como os direitos civis e políticos, aqueles de caráter individual que, no Século XVII, faziam oposição ao Estado.

A segunda geração é caracterizada no Século XX pelos direitos de igualdade, como os direitos sociais, culturais e econômicos, bem como direitos da sociedade. 
E na terceira geração os direitos de fraternidade ou solidariedade, como o direito ao meio ambiente ecologicamente equilibrado, à paz, à qualidade de vida, à conservação e utilização do patrimônio histórico e cultural, à comunicação, entre outros.

Inclusive com reconhecimento do Supremo Tribunal Federal: "Direito ao meio ambiente ecologicamente equilibrado: a consagração constitucional de um direito típico de terceira geração" (Supremo Tribunal Federal. Recurso Extraordinário no 134.297-8/SP. Primeira Turma, Rel. Min. Celso de Mello, DJ de 22/11/1995, p. 30.597).

Atualmente, vários indivíduos têm perdido suas moradias, familiares, pertences ou a própria vida em consequência das catástrofes ambientais. Dessa forma, além da violência e dos conflitos militares, as tragédias ambientais têm ceifado milhares de vidas, gerando êxodo destas pessoas destes lugares ou forçando-os a recomeçarem do zero, pois todos os seus bens acabam sendo destruídos. Conforme entendimento de Robert e Séguin (2000, p. 42). ROBERT, Cinthia; SÉGUIN, Elida. Direitos Humanos, acesso à justiça: um olhar da defensoria pública. Rio de Janeiro: Forense, 2000.

Por fim, sem a eficaz preservação, o maior dos direitos fundamentais, que é a vida humana, é posta em perigo, podendo no futuro deixar de existir. Esse é, senão o maior motivo da ascensão da conservação ao meio ambiente como um direito fundamental, sendo dever tanto do poder público e de toda sociedade, zelar pela sua preservação.

\subsection{DIMENSÃO DO DIREITO FUNDAMENTAL EM REFERÊNCIA AO MEIO AMBIENTE}

Ao longo da história, o homem se desenvolveu e prosperou como individuo através da exploração dos recursos naturais e consequentemente através da exploração da agricultura. E devido à utilização desses recursos a humanidade se expandiu por todo mundo, colonizando novas áreas. Por conseguinte, essa expansão acarretou a necessidade de uma produção maior de alimentos, carecendo assim de novas áreas agricultáveis, ocasionando uma degradação dos ecossistemas e causando, assim, um contraponto de ideias, pois da mesma forma que o homem necessita se desenvolver a fauna e a flora precisam ser protegidos. 
O primeiro Código Florestal Brasileiro teve sua origem no ano de 1934 por meio do Decreto 23.793. O mesmo permitia a abertura de no máximo 75\% (setenta e cinco por cento) das áreas de mata da propriedade. Também foi definida a obrigatoriedade de uma espécie de "reserva florestal" nas propriedades, cujo objetivo era assegurar o fornecimento de carvão e lenha, combustível de grande importância utilizado na época.

Neste texto ficou estabelecido o conceito de floresta e as dimensões para sua proteção, tendo em vista o grande desmatamento decorrente do desenvolvimento agrícola da época. Os governantes daquele tempo perceberam que as matas e florestas estavam cada vez mais longe do perímetro urbano, o que dificultava e encarecia o transporte de lenha. Dessa forma, normas foram criadas para coibir a extração madeireira da época. (BRASIL, 1934). BRASIL. Decreto. Decreto n 23.793 de 23 de Janeiro de 1934. Aprova o código florestal. Brasil, 1934. Disponível em: <http://www.planalto.gov.br/ccivil_03/decreto/1930-1949/D23793.htm>. Acesso em 11 set. 2017

O texto permaneceu até 1965 , ano em que é aprovada a Lei n4.771/65. Este Código, em seu conteúdo, ampliou a proteção e conservação da flora, e o mesmo estabeleceu claras limitações ao uso da propriedade privada por serem as florestas bem de interesse de toda sociedade brasileira, inserindo o instituto das áreas de preservação permanente, que é o objeto do presente trabalho. (Disponível em: http://www.planalto.gov.br/ccivil_03/leis/14771.htm. Acesso em: 11 set. 2017).

O citado Código caracterizava a área de preservação permanente como o ente ambiental, que possuía o papel de conservar os recursos hídricos, a paisagem, a biodiversidade, a estabilidade geológica, dentre outros critérios. Já a reserva legal tinha como objetivo manter e conservar a fauna e flora nativa, os processos ecológicos e utilização sustentável dos recursos naturais, e estas deviam estar localizadas dentro das propriedades rurais, possuindo, também, porcentagens variáveis no tamanho conforme com a região do país em que se encontravam.

No entanto, o Código Florestal de 1965 e posteriores modificações estabeleceram, entre outras questões, as limitações ao direito de propriedade no que se refere ao uso e exploração do solo e das florestas e demais formas de vegetação, até entrar em vigor o atual Código Florestal Lei $\mathrm{n}^{\circ} 12.651$, de 25 de maio de 2012. 
Mais conhecido como Novo Código Florestal, no qual a preocupação central está voltada para o desenvolvimento sustentável, aliado a realização do desenvolvimento econômico, indispensável para o progresso nacional e eliminação da pobreza (art. 1-A). Dessa forma, o atual Código Florestal busca incorporar a preservação do meio ambiente ao direito de propriedade, mantendo em vigor os institutos da Reserva Legal e das Áreas de Proteção Permanentes e, “[...] coloca o país em posição de destaque, por ser o único do mundo que vem discutindo leis que harmonizem conservação ambiental com a atividade agrícola" (FRANCO, L. O Brasil discute como produzir e preservar, in: Revista Globo Rural: A tecnologia que dá vida ao solo, Edição 320, de junho de 2012, Editora Globo). O texto também assegura tratamento diferenciado ao minifundiários, instituindo as áreas rurais consolidadas.

Percebe-se, por conseguinte, que o direito de propriedade continua em oponível ao preceito erga omnes, ou seja, para todos, mas seu uso e gozo são reduzidos e direcionados por uma função social, expondo a imprescindível coexistência entre o direito ambiental e o direito de propriedade, como direitos fundamentais.

\subsection{CONCEITO E DEFINIÇÕES ÁREA DE PRESERVAÇÃO PERMANENTE}

De acordo com o artigo 21, inciso IX da Constituição Federal a União tem competência material para elaborar e executar planos de ordenação do território e desenvolvimento econômico e social, trazendo então ao ordenamento jurídico brasileiro espaços territoriais especialmente protegidos.

Ainda o artigo 225, $\S 1^{\circ}$, inciso III do diploma constitucional, regulamenta que cabe ao Poder Público definir em todas as unidades da federação, espaço territoriais e seus componentes a serem especialmente protegidos, que só poderão ser suprimidos ou alterados por lei.

Conforme José Afonso da Silva:

Áreas geográficas públicas ou privadas (porção no território nacional), dotadas de atributos que requeiram sua sujeição, pela lei, a um regime jurídico de interesse público, que implique sua relativa imodificação e sua utilização sustentada, tendo em vista a preservação e proteção da sua integralidade de amostras de toda a diversidade de ecossistemas, a proteção ao processo evolutivo das espécies, a 
preservação e proteção dos recursos naturais. (SILVA, José Afonso da. Direito Ambiental Constitucional. 7 ed. São Paulo: Malheiros, 2009, p. 230).

O conceito legal de área de preservação permanente, objeto deste trabalho, surgiu na Medida Provisória n. 2.166 de 24/08/2011, que alterou o Código Florestal vigente á época (Lei 4.771/1965) em seu artigo $1^{\circ}, 2^{\circ}$, inciso II, com a seguinte redação:

\footnotetext{
Área protegida nos termos dos arts. $2^{\circ}$ e $3^{\circ}(\ldots)$ coberta ou não por vegetação nativa, com a função ambiental de preservar recursos hídricos, a paisagem, a estabilidade geológica, a biodiversidade, o fluxo gênico de fauna e flora, proteger o solo e assegurar o bemestar das populações humanas. (http://www.planalto.gov.br/ccivil $03 / \mathrm{mpv} / 2166-67 . \mathrm{htm})$.
}

A área de preservação permanente é delimitada no artigo $3^{\circ}$, II, da Lei ${ }^{\circ} 12.651$, de 25 de maio de 2012, como sendo uma área de proteção ambiental, podendo ser recoberta por vegetação nativa ou não, e que tem como funções: a proteção dos recursos hídricos, da estabilidade do solo e da diversidade biológica, da paisagem, bem como a facilitação do fluxo gênico de fauna e flora, assegurando dessa forma o bem-estar das populações humanas.

Paulo Affonso Leme Machado resume que as áreas de preservação permanente têm por objetivo, salvaguardar os cursos de água, impedir assoreamentos de rios, evitar alagamentos e estabilizar montes, serras e montanhas. (MACHADO, Paulo Affonso Leme. Direito Ambiental Brasileiro, $9^{a}$ ed., São Paulo: Malheiros, 2001, p. 698).

Com relação à área de preservação permanente, esta é resguardada, recoberta ou não por vegetação nativa, com o papel ambiental de resguardar os a biodiversidade, recursos hídricos, a estabilidade geológica, a paisagem, e facilitar o deslocamento genético de fauna e flora, salvaguardar o solo e garantir o bem-estar das populações humanas (artigo $3^{\circ}$, II da Lei n. ${ }^{\circ}$ 12.651/2012).

A área de preservação permanente pode recair em áreas rurais ou urbanas e sua diferenciação como área resguardada leva em conta a sua localização, como, por exemplo, as faixas ribeirinhas de todo curso d'água nativo perene e intermitente, reservatórios d'água artificiais derivados de represamento ou barramento de cursos d'água naturais, margens de lagos e lagoas naturais, áreas ao redor de nascentes e dos olhos d'água, os man- 
guezais, as restingas, as costas dos tabuleiros ou chapadas, os topo de morros, montanhas, serras e montes, as veredas e as áreas com altitude superior a 1.800 metros.

Antunes alimenta o juízo de que as funções ambientais das áreas de preservação permanente necessitam se encontrar efetivamente presentes, diferenciando-se como implicações de legalidade, o que, segundo o autor, encontra acolhida na Lei de Introdução ao Direito Brasileiro, especialmente quando estabelece que o aplicador da lei deve analisar os fins sociais da norma, sendo estes, no caso, "a proteção de áreas que efetivamente desempenhem as funções ambientais tipificadas na lei" (ANTUNES, Paulo de Bessa. Comentários ao novo código florestal. São Paulo : Atlas, 2013 p. 66).

Dessa forma, áreas de preservação permanente estabelecem limitação legal ao direito de propriedade. A proteção destas áreas tem por objetivo a proteção do leito e das bordas de cursos d'água, topos de morros e encostas evitando deslizamentos e assoreamentos de terras e estas também tem importância fundamental na manutenção de corredores ecológicos que promovem a o trânsito e procriação da fauna e da flora indispensável para a sua manutenção.

\section{DIREITO DE PROPRIEDADE}

No sentido amplo propriedade se traduz em um conceito jurídico de apropriação de bem corpóreo, enquanto em um sentido mais literal, o termo está ligado a algo que pertence a alguém.

\subsection{DEFINIÇÃO E CONCEITO}

É difícil definir o exato instante em que se aflora o direito de propriedade e em qual sociedade este organismo se originou. Porém pode-se constatar, no transcorrer da história da sociedade humana, que existem alguns grupos étnicos que já tratavam do direito de propriedade, contudo não com a visão que se tem na sociedade atual.

Nas sociedades mais antigas, Fustel de Coulanges nos ensina que: 
Os tártaros reconheciam o direito de propriedade com relação aos rebanhos, mas não o entendiam quando se tratava de solo. Dentre os antigos germanos, o solo não pertencia a ninguém; a cada ciclo de estações a tribo recomendava a cada um dos seus membros a área para cultivar, e mudava a área no ano seguinte. Observa-se o mesmo com parte da raça semita e com determinados povos eslavos.

Com relação ao direito romano, o direito à propriedade possuía viés individualista, ou seja, a sociedade já o entendia como propriedade privada. Contudo, o conceito de propriedade era restrito ao lar e às cerimônias religiosas.

Dessa forma, o conceito de direito de propriedade estava atrelado a religião, haja vista que "o deus da família necessitava ter moradia fixa", portanto a família, vinculada ao fogo, tinha forte ligação com a propriedade.

Com o declínio do império romano, floresce a Idade Média. Neste período, surge o feudalismo na Europa, que dividiu os poderes referentes à propriedade, no qual o senhor feudal era o titular da terra, enquanto que os camponeses recebiam um lote de terra e amparo devido a prestação de seus serviços.

Contudo, a era feudal entra em crise ante o crescimento da população e a mercantilização que, após, com seu declínio, nasceu a forte ideia de que o direito privado, cujo a base era o direito a propriedade (usar, gozar e dispor), não poderia em nenhuma hipótese ser infringido.

A revolução Francesa rejeitou o modelo feudal e tentou acabar com as diferenciações de classes sociais (liberdade, fraternidade e igualdade), assumindo aspecto individualista na Declaração do Homem e do Cidadão, de 1789, anunciada pela Assembleia Constitucional da Revolução Francesa, de forma que reavivou a ideia de que a propriedade era tida como inviolável e protegida.

Logo após a $1^{\text {a }}$ Guerra Mundial, os governos decidiram interferir na economia devido aos graves problemas sociais oriundos da guerra, surgindo o pensamento de que o direito de propriedade deve atender à justiça social.

\subsection{PROTEÇÃO CONSTITUCIONAL À PROPRIEDADE}


A Constituição Federal, em seu art. $5^{\circ}$, nos dá a ideia de domínio estatal, teoricamente ilimitado. Contudo, será limitado todas as vezes que confrontar direitos e garantias individuais. Além disso, o $\S 1^{\circ}$ deste artigo determinou tais direitos como de aplicação adjacente e modificou os direitos e garantias em cláusulas pétreas, como antevisto no art. $60, \S 4^{\circ}$, Inciso IV.

Moraes (2002, p. 33) destaca que o direito de propriedade é um direito constitucional; assim sendo, seu cerceamento por ato estatal, seja instituindo ou executando dispositivo de lei, deve o particular ter uma recompensa. Não se está coibindo o Estado de agir, mas de assim fazê-lo sem prejudicar parte da sociedade em detrimento da outra. Seria inaceitável a possibilidade de se retirar direitos já adquiridos.

Examina-se que o Estado não pode suprimir direitos e garantias fundamentais conquistados constitucionalmente tais como os direitos e garantias individuais.

De acordo com Borges (2007, p. 61), este assegura que "A garantia do ius proprietatis se estende além do que se refere ao simples dominium, mas se completa também, no que diz respeito ao instituto da posse".

O direito de propriedade rural se materializa exercendo a função social que se explana no uso da terra de modo coerente e adequado, inclusive, atendendo à normativa de conservação dos recursos naturais e do meio ambiente, ex vi legis do art. 186, II e IV da CF/88.

Pode-se observar ainda no conteúdo da propriedade que para salvaguardar sua proteção podemos nos utilizar dos meios legais próprios, resguardando o livre exercício dos atributos acima mencionados. Dessa forma, ao sinal de ameaça ao exercício do uso, gozo e disposição, tem o proprietário o direito de invocar os dispositivos jurídicos que serão elencados a diante neste trabalho com o fito de reavê-lo.

\subsection{DIREITO DE PROPRIEDADE NA ESFERA CIVIL}

A propriedade é uma entidade definida pelo próprio Código Civil Brasileiro, que resguarda o direito ao proprietário de usar, gozar e dispor de um bem, além de reavê-lo, quando este esteja sob a posse de outrem de maneira injusta. 
Dessa forma, o Código Civil traz em seu artigo 1.228 caput uma apreciação histórica do que seja a propriedade, de tal modo seu $\S 1^{\circ}$, traz uma consideração analítica:

Art. 1.228. O proprietário tem a faculdade de usar, gozar e dispor da coisa, e o direito de reavê-la do poder de quem quer que injustamente a possua ou a detenha.

$\S 1^{\circ} \mathrm{O}$ direito de propriedade deve ser exercido em consonância com as suas finalidades econômicas e sociais e de modo que sejam preservados, de conformidade com o estabelecido em lei especial, a flora, a fauna, as belezas naturais, o equilíbrio ecológico e o patrimônio histórico e artístico, bem como evitada a poluição do ar e das águas.

Ao analisarmos estes conceitos, pode-se verificar que para existir o direito de propriedade, devem-se estar intrínsecos os elementos basilares para a mesma, que são o uso, gozo, disposição e reivindicação. Não se terá a propriedade, caso um destes elementos seja suprimido. Sempre resguardando o atendimento de sua função social, cuja definição é inseparável do requisito obrigatório do uso racional da propriedade e dos recursos ambientais, que estão contidos no texto legal.

Por conseguinte, pode-se dizer que o direito de propriedade, embora não seja absoluto, tem particularidades absolutas naquilo que diz respeito a sua oponibilidade erga omnes; verifica-se este como o mais completo dos direitos reais que dele se emanam, podendo o proprietário ou possuidor desfrutar e dispor de seu bem da maneira que lhe convir, desde que as normas do ordenamento jurídico que limitam em razão do interesse público.

\section{Segundo Maria Helena Diniz:}

O direito de usar a coisa é o de tirar dela todos os serviços que ela pode prestar, sem que haja modificação em sua substância. O titular do jus utendi pode empregá-lo em seu próprio proveito ou no de outrem., bem como deixar de utilizá-lo, guardando-o ou mantendoo inerte. Usar o bem não é apenas retirar vantagens, mas também ter o bem em condições para servir. O jus utendi é o direito de usar a coisa, dentro das restrições legais, a fim de evitar o abuso do direito, limitando-se, portanto, ao bem estar da coletividade. O jus fruendi exterioriza-se na percepção dos frutos e na utilização dos produtos da coisa. É o direito de gozar da coisa ou de explorá-la economicamente. $\mathrm{O}$ jus abutendi ou disponendi equivale ao direito de dispor da coisa ou poder de aliená-la a título oneroso (venda) ou gratuito (doação), abrangendo o direito de consumi-la e o poder de gravá-la de ônus (penhor ou hipoteca, servidão etc) ou de submetêla ao serviço de outrem (...) E, finalmente, rei vindicatio é o poder que tem o proprietário de mover ação para obter o bem de quem 
injustamente o detenha, em virtude do seu direito de sequela, que é característica do direito real. (DINIZ, Maria Helena, Função social da propriedade: Mito ou Realidade; Revista Síntese de Direito Civil e Processual Civil; Vol 03 p.75, Porto Alegre; Jan-Fev-2002. P. 108).

Pode-se concluir, sobre a referida norma legal, que houve um evidente distanciamento do egocentrismo histórico, uma vez que a legislação adveio a buscar uma maior função social da propriedade em beneficio da coletividade, buscando a defesa do meio ambiente e do patrimônio histórico, não mais apenas em beneficio único e exclusivo do proprietário. Dessa forma, o ônus do desempenho da função social da propriedade fica a cargo do proprietário ou possuidor do imóvel.

\section{4}

\section{O ÔNUS DO PROPRIETÁRIO PELA LIMITAÇÃO IMPOSTA PELAS APPS}

O ser humano precisa sobreviver e está vinculado à exploração dos recursos naturais para a produção de mantimentos que se desenvolve na propriedade rural. As limitações ambientais no imóvel rural, deste modo, culminam com desenvolvimento sustentável, sendo o proprietário rural forçado a conciliar a produção agrícola com a preservação da natureza.

\section{5}

\section{FUNÇÃO SOCIAL DA PROPRIEDADE}

A função social da propriedade é elencada pela Constituição Federal como garantia fundamental, sendo esta função de extrema importância para a ordem financeira e econômica no Brasil.

A Constituição Federal assegura em seu artigo $5^{\circ}$, inciso XXIII que: "a propriedade rural atenderá a sua função social". Premissa também elencada em seu artigo 170, constitui também que a ordem econômica tem por fim garantir a todos uma vida digna, orientados, de acordo com os princípios da defesa do meio ambiente, da propriedade privada e da função social da propriedade. 
Quando se menciona que a propriedade privada deve possuir um caráter social, na realidade, está se alegando que ao proprietário se estabelece o dever de cumprir o seu direito de propriedade não mais, simplesmente, em seu próprio e particular interesse, mas, também, em beneficio da coletividade.

Ressaltando ainda que a propriedade urbana, conforme o art. 182, $\S 2^{\circ}$, da Constituição Federal atende sua função social quando atinge as exigências basilares de ordenação da cidade proclamas no Plano Diretor.

Esclarece Lemos que o meio urbano desempenha a sua função ambiental quando afiança a todos o direito ao meio ambiente urbano equilibrado ecologicamente: água, esgoto, luz, áreas verdes, lazer e cultura, transporte público, etc. (LEMOS, Patrícia Faga Iglecias. Meio ambiente e responsabilidade civil do proprietário. 2. ed. Revista dos Tribunais, 2012. P. 84).

Examina-se uma dessemelhança entre a função social ambiental nas cidades e no meio rural: enquanto no meio rural o proprietário deve averbar vinte por cento a oitenta por cento de sua propriedade como área de reserva legal e preservando ainda as áreas preservação permanente, no meio urbano não há esta exigência, e quando há (o que ocorre em loteamentos novos), as áreas verdes são mescladas com as áreas institucionais e a responsabilidade objetiva de proteção fica a cargo das prefeituras.

Estabelece a Constituição Federal, em seu artigo 225, que todos possuem direito a uma condição de vida ecologicamente equilibrada, atribuindo ao Poder Público e à sociedade como um todo este ônus e, e no meio rural o proprietário rural, fica com este encargo.

Observa-se a Constituição Federal no artigo 186 que prevê que:

\footnotetext{
Art. 186. A função social é cumprida quando a propriedade rural atende, simultaneamente, segundo critérios e graus de exigência estabelecidos em lei, aos seguintes requisitos:

I - aproveitamento racional e adequado;

II - utilização adequada dos recursos naturais disponíveis e preservação do meio ambiente;

III - observância das disposições que regulam as relações de trabalho;

IV - exploração que favoreça o bem-estar dos proprietários e dos trabalhadores
}

Nota-se que existem restrições ao direito de propriedade com a finalidade de restringir abusos e evitar que seja desempenhado de maneira que possa ocasionar perdas ao bem-estar social, permitindo, desta forma, o 
implemento do desempenho econômico-social da propriedade, de acordo com as garantias constitucionais, apontando as condições para que ela seja de maneira econômica viável e produtiva, atendendo ao progresso econômico e os princípios do direito social.

\title{
3.6 FUNÇÃO SOCIOAMBIENTAL DA PROPRIEDADE
}

Atualmente, necessitamos pensar não mais na simples ideia de função social da propriedade, mas sim na função socioambiental da propriedade. O proprietário fica obrigado a proteger, atender e conservar o meio ambiente.

\begin{abstract}
Assim, o proprietário do bem socioambiental, ou seja, daquele bem essencial para a manutenção da vida de todas as espécies e de todas as culturas, fica sujeito aos comportamentos apontados. Há um direito à preservação do bem, que é superior ao direito individual de propriedade. É o que chamamos de direito socioambiental de titularidade difusa. A proteção volta-se ao bem, pouco importando a sua titularidade no caso concreto. Por isso, o bem público estará sujeito às mesmas regras do bem privado e os direitos socioambientais são exercidos sobre bens alheios. (LEMOS, 2008, p. 82).
\end{abstract}

Com relação ao meio ambiente, o proprietário não pode explorar sua propriedade de forma oposta aos interesses das atuais e das próximas gerações, gerando danos à qualidade de vida e, por conseguinte, ao próprio direito básico à vida.

Ainda conforme entendimento do Supremo Tribunal Federal:

O acesso à terra, a solução de conflitos sociais, o aproveitamento racional e adequado do imóvel rural, a utilização apropriada dos recursos naturais disponíveis e a preservação do meio ambiente constituem elementos de realização da função social da propriedade. A desapropriação neste contexto - enquanto sanção constitucional imponível ao descumprimento da função social da propriedade - reflete importante instrumento destinado a dar consequência aos compromissos assumidos pelo Estado na ordem econômica e social. Incumbe, ao proprietário da terra, o dever jurídico social de cultivá-la e de explorá-la adequadamente, sob pena de incidir nas disposições constitucionais e legais que sancionam os senhores de imóveis ociosos, não cultivados e/ou improdutivos, pois só se tem por atendida a função social que condiciona o exercício do direito de propriedade, quando o titular do domínio cumprir a obrigação (1) favorecer o bem estar dos que na terra labutam; (2) de manter níveis satisfatórios de produtividade; (3) de assegurar a conservação dos recursos naturais; e (4) de observar as disposições legais 
que regulam as justas relações de trabalho entre os que possuem o domínio e aqueles que cultivam a propriedade (STF. ADI 2.213MC, Rel. Ministro Celso de Melo, j. 04.04.2002).

De acordo com o artigo 225 da $\mathrm{CF} / 88$, a propriedade deverá possuir uma função ambiental e também função social. Dessa forma, quando se refere ao bem avaliado como essencial para a conservação da vida, nos encontramos com o desempenho socioambiental da propriedade. Sendo assim, a função social acaba sendo um dado definitivo do mantimento do direito de propriedade. Entretanto, de acordo com o art. $5^{\circ}$, XXII, da referida Carta, é mister conhecer que o descumprimento dessa função não aprova o esvaziamento da propriedade de seu teor mínimo sem ressarcimento, em que incidam opiniões adversas.

Percebe-se, de acordo com o que anteriormente fora elucidado, que a propriedade rural exerce a função socioambiental quando é empreendida de acordo com a capacidade natural do solo, mantendo o potencial produtivo, resguardando as características do ecossistema local, a característica dos recursos ambientais. Dessa forma, empregada de forma racional para conservar a estabilidade ecossistêmica, defendendo a saúde e a qualidade de vida das sociedades vizinhas.

É indispensável a conservação ambiental para garantir a continuação da espécie humana no planeta e, para ter uma condição de vida mais perfeita e mais adequada, mas, também, é imprescindível a exploração dos recursos naturais para produção dos bens de consumo necessários no cotidiano da sociedade para a sua sobrevivência.

\subsection{LIMITAÇÃO AO DIREITO DE PROPRIEDADE E O ÔNUS DO PROPRIETÁRIO}

O direito de propriedade, juntamente com a função social prevista no ordenamento jurídico, promove a preservação do meio ambiente nas propriedades rurais, fomentando o bem-estar da coletividade como outrora já mencionado. Contudo, essa preservação traz consigo uma limitação do uso do imóvel rural juntamente com o ônus de sua conservação.

Para fazer valer o direito ao meio ambiente preservado, a Constituição Federal institui que compete ao Poder Público deliberar, em todas as unidades da Federação, espaços territoriais e seus membros a serem no- 
tadamente protegidos, sendo a modificação e a supressão admitidas exclusivamente através de lei, proibida qualquer utilização que danifique a integridade das características que aprovem sua proteção. (art. 225, § $1^{\circ}$, III).

Em Direito ambiental é possível que um bem, público ou privado, seja de uso comum do povo, em uma conotação diversa à classificação tradicional dos bens públicos adotada pelo Direito Administrativo, que divide os bens das pessoas jurídicas de direito público em dominicais, de uso comum do povo e de uso especial, tendo em conta a natureza autônoma do bem ambiental, naturalmente difuso.

Como exemplo, uma pessoa proprietária de uma área com cobertura florestal tem o direito real, mas por outro lado, não poderá desmatar sem licenciamento ambiental acima dos limites legais de tolerância. Assim, o bem é privado, mas o seu equilíbrio ambiental é direito difuso, imaterial, de terceira geração, de todo o povo e tutelável automaticamente. (AMADO, Frederico. Direito Ambiental. Editora JusPodivm. 8a edição. Salvador: 2017 p.214).

O artigo $7^{\circ}$ do Código Florestal é bastante claro na responsabilização do proprietário da área, possuidor ou ocupante, a qualquer título, pessoa física ou jurídica, de direito público ou privado na manutenção e conservação da vegetação situada na área de preservação permanente.

Para Celso Antônio Bandeira de Mello, ainda que seja peculiar das limitações administrativas estabelecer deveres de renúncia, não se almejando por meio delas captar ações positivas, o princípio da função social da propriedade é exceção à regra, já que o proprietário deve destinar ao seu imóvel uma função social útil. (MELLO, Celso Antônio Bandeira de Mello. Curso de Direito Administrativo. 26a ed. São Paulo: Malheiros Editores, 2009. P.795).

As limitações administrativas derivam do poder de polícia da administração pública, com referência na obrigação do atendimento da função socioambiental da propriedade.

O poder de polícia conceituado no artigo 78 do Código Tributário Nacional $^{2}$ advém da necessidade do Poder Público em evitar qualquer tipo

\footnotetext{
${ }^{2}$ Art. 78. Considera-se poder de polícia atividade da administração pública que, limitando ou disciplinando direito, interesse ou liberdade, regula a prática de ato ou abstenção de fato, em razão de interesse público concernente à segurança, à higiene, à ordem, aos costumes, à disciplina da produção e do mercado, ao exercício de atividades econômicas dependentes de concessão ou autorização do Poder Público, à tranquilidade pública ou ao respeito à propriedade e aos direitos individuais ou coletivos.
} 
de abuso no exercício do direito individual frente ao interesse público, lembrando-se do Princípio da Proporcionalidade, já que não existe direito absoluto, sendo necessário basear-se de forma adequada e proporcional em sentido estrito; visto o dever constitucional do Poder Público em promover a conservação do meio ambiente.

Em caso de desapropriação de imóvel por utilidade pública ou interesse social há posição do Superior Tribunal de Justiça pela exclusão da indenização a cobertura florestal em área de preservação permanente (REsp. 935.888/208).

Há uma decisão concedida pelo Tribunal Regional Federal da $4^{\mathrm{a}}$ Região que ainda causa polêmica no mundo jurídico já que abriu precedente, mas ainda aguarda decisão do Superior Tribunal de Justiça - REsp. 1240915:

A concorrência do direito ao ambiente e do direito á moradia requer a compreensão dos respectivos conteúdos jurídicos segundo a qual a desocupação forçada e demolição da moradia depende da disponibilidade de alternativa à moradia. Cuidando-se de família pobre, chefiada por mulher pescadora, habitando há largo tempo e com aquiescência do Poder Público a área de preservação ambiental em questão, ausente risco à segurança e de dano maior ou irreparável ao ambiente, em questão, ausente risco à segurança e de dano maior ou irreparável ao ambiente, fica patente o dever de compatibilização dos direitos fundamentais envolvidos. Proteção da dignidade da pessoa humana, na medida em que o sujeito diretamente afetado seria visto como meio cuja remoção resultaria na consecução da finalidade da conduta estatal, sendo desconsiderada como fim em si mesmo de tal atividade. Concretização que busca prevenir efeitos discriminatórios indiretos, ainda que desprovidos de intenção, em face da pretensão de despejo e demolição atinge mulher chefe de família, vivendo em sua residência com dois filhos, exercendo de modo regular, atividade pesqueira. A proibição da discriminação indireta atenta para as consequências da vulnerabilidade experimentada por mulheres pobres, sobre quem recaem de modo desproporcional os ônus da dinâmica gerados das diversas demandas e iniciativas estatais e sociais. (TRF4. AC 2006.72.04.0038874, Rel. Juiz Federal Roger Raupp Rios, j. 12.05.2009).

No entanto, caso ocorra do desmatamento em área de preservação permanente o poluidor (proprietário/possuidor) deve arcar com as con- 
sequências, mesmo não sendo o autor do dano ao meio ambiente, a chamada obrigação propter rem, este entendimento já está consolidado no Superior Tribunal de Justiça (AgRg no REsp 1.206.484, de 17.03.2011).

Em recentíssima decisão o Supremo Tribunal Federal foi bem claro no seguinte sentido:

ADMINISTRATIVO. LIMITAÇÃO AO DIREITO DE PROPRIEDADE. IMPOSSIBILIDADE DE SUPRESSÃO A MATA SILIAR EM ÁREA DE PRESERVAÇÃO ERMANENTE. INDENIZAÇÃO. DESCABIMENTO. HONORÁRIOS ADVOCATÍCIOS. COMPENSAÇÃO. OSSIBILIDADE. ILÍCITO AMBIENTAL. PERPETUAÇÃ̃. MULTA. MANUTENÇÃO. RELEVÂNCIA PARA O CONTROLE DO ESFORÇO DEPREDATÓRIO EM APP.1.- A hipótese dos autos não trata de desapropriação indireta, mas tão somente de pretensão à indenização em virtude de limitação administrativa perpetrada pelo art. $4^{\circ}$ do Código Florestal, que veda a supressão de mata ciliar em área de preservação permanente. Portanto, resta afastada a natureza de ação real, porque não houve desapossamento, caracterizando-se como ação pessoal contra a União, visando indenização pela limitação de uso da propriedade, cujo prazo prescricional rege-se pelo Decreto 20.910/32.2.A limitação de uso não enseja indenização porque a gratuidade é característica pertinente ao instituto. 3.- É cabível a compensação de honorários advocatícios, na hipótese de sucumbência recíproca, mesmo quando uma das partes litiga sob o pálio da Assistência Judiciária Gratuita.4.- Aquele que perpetua o ilícito ambiental também comete dano ao meio ambiente.5.- Não havendo nenhuma ilegalidade no procedimento administrativo que cominou a multa aplicada, e tendo-se em conta que a multa é de extrema importância para o controle do esforço depredatório sobre a área de preservação permanente compreendida pelas matas ciliares do Rio Iguaçu, cuja relevância foi acima exposta, tem-se que a sua imposição por parte da autarquia é absolutamente necessária e devida. (e-STJ, fls. 353/354). (REsp. 1.236.772 PR. Relator Ministro OG Fernandes).

Conclui-se que a área de preservação permanente é uma espécie de limitação administrativa, visto que é estabelecida por lei - Código Florestal, fixada pelo Estado, tratando-se assim norma impositiva de restrição de uso do imóvel rural, considerando que as mesmas jamais seriam recompostas ou preservadas no domínio privado desestabilizaria o meio ambiente e o ecossistema equilibrado, prejudicando a exploração do agricultor, que tem a restrição ao uso da sua terra.

Mesmo com a possibilidade de o produtor rural ser beneficiado com o pagamento a serviços ambientais de conservação ${ }^{3}$, obter facilitação

${ }^{3}$ O Pagamento por Serviços Ambientais (PSA) é um tipo de programa que compensa financeiramente os produtores rurais pela área designada à conservação dos ecossistemas, em 
de crédito agrícola e dedução das áreas do cálculo do Imposto sobre a Propriedade Territorial Rural ${ }^{4}$. Tais benefícios não são capazes de realmente compensar a não utilização econômica de determinada porcentagem da propriedade rural causando certo ônus ao produtor.

\section{CONSIDERAÇÕES FINAIS}

Coexiste no mesmo patamar de proteção constitucional: o direito de propriedade, o direito ao meio ambiente ecologicamente equilibrado e o de exploração econômica. Estes são apreciados como direitos fundamentais na Constituição Federal de 1988 de terceira geração ou dimensão.

A função intrínseca da propriedade é a econômica, mas ao longo do tempo, com o advento de legislações mais modernas, a mesma passou a estar relacionada a um conteúdo social, de maneira que esta tenha também atender as necessidades da coletividade.

Dessa forma, o modelo de produção e consumo de massa comprometeu significativamente o meio ambiente devido à exploração de seus recursos naturais, diante disso o Direito Ambiental foi reformado com enfoque no desenvolvimento sustentável, conforme tipificado no artigo 225 da citada Constituição Federal.

Hoje, entretanto, todos conscientes de serem exauríveis os recursos naturais, é irrefutável o interesse na conservação do ecossistema ecologicamente equilibrado. Esta conservação ocorre devido à regulamentação do seu uso de maneira sustentável, através de leis e normas elencadas no Direito brasileiro.

Isto posto, propriedade rural de acordo com a legislação vigente deverá exercer a função socioambiental de modo que sua atividade seja empreendida de acordo com a capacidade natural do solo, mantendo o potencial produtivo, resguardando as características do ecossistema local, a

detrimento do uso particular. A ideia é que os beneficiados façam pagamentos diretos, contratuais e condicionais aos proprietários rurais para que pratiquem a conservação e a restauração de ecossistemas. Os casos mais conhecidos no mundo estão relacionados às áreas de mananciais, onde a conservação dos ecossistemas permite a provisão de água, o controle de enchentes, o escoamento e o armazenamento de água. (http://www.cruesp.sp.gov.br/?p=11110 acesso 19.09.2017).

${ }^{4}$ A Lei n. $9393 / 96$ prevista no art. $10, \S 1^{\circ}$, II , a, isenta do pagamento do Imposto Territorial Rural as áreas de preservação permanente. 
característica dos recursos ambientais. Dessa forma, empregada de forma racional para conservar a estabilidade ecossistêmica, defendendo a saúde e a qualidade de vida das sociedades vizinhas.

Nesta legislação fica claro e evidente a importância das áreas de preservação permanente, pois estas são responsáveis pela proteção do leito e das bordas de cursos d'água, topos de morros e encostas, evitando deslizamentos e assoreamentos de terras. Estas também têm importância fundamental na manutenção de corredores ecológicos que promovem a o trânsito e procriação da fauna e da flora indispensável para a sua manutenção.

Contudo, as áreas de preservação permanente se transfiguram em limitações administrativas, pois fica a encargo do proprietário rural ou possuidor sua conservação, proteção e, em alguns casos, recomposição, somente podendo utilizá-la em casos estritamente específicos e de modo sustentável. Mesmo com os benefícios como com o pagamento a serviços ambientais de conservação, obter facilitação de crédito agrícola e dedução das áreas do cálculo do Imposto sobre a Propriedade Territorial Rural, tais não são condizentes para compensar a não exploração de determinada porcentagem da área.

Dessa forma, como a função econômica de algo de propriedade de alguém é satisfazer a necessidade do mesmo, a inserção das áreas de preservação permanente em propriedades privadas restringe a utilização do bem. A função da propriedade é então produzir atingindo os interesses do proprietário no sentido de realizar a função econômica da propriedade, mas com o respeito a função social e socioambiental da propriedade, sempre objetivando um ecossistema equilibrado.

\section{REFERÊNCIAS BIBLIOGRÁFICAS}

ANTUNES, Paulo de Bessa; Direito Ambiental. São Paulo: Atlas.

ASCENSÃO, José de Oliveira, Direito Civil - Reais. Coimbra, Coimbra Editora, 4ª Ed., p. 187, 1987.

DUNDA, Bruno Faro Eloy. O Conceito e as Funções das Áreas de Preservação Permanente. Disponível em: <https://blog.ebeji.com.br/o-conceito-e-as-funcoes-das-areas-de-preservacao-permanente/>. Acesso em 07/10/2017.

FIORILlO, Celso Antônio Pacheco. Curso de Direito Ambiental Brasileiro, São Paulo: Saraiva. 
GOUVÊA, Yara Maria Gomide. Novo código florestal: comentários à Lei 12.651, de 25 de maio de 2012, à Lei 12.727, de 17 de outubro de 2012 e do Decreto 7.830, de 17 de outubro de 2012 / coordenação Édis Milaré, Paulo Affonso Leme Machado. 2 ed. São Paulo : Editora Revista dos Tribunais, 2013.

GRANZIERA, Maria Luiza Machado. Direito Ambiental. 4ª ed. São Paulo: Atlas, 2015.

MACHADO, Paulo Afonso Leme. Direito ambiental brasileiro. São Paulo: Malheiros.

MEIRELLES, Hely Lopes. Direito Administrativo Brasileiro 38 a edição - São Paulo: Malheiros Editores, 2012.

MELLO, Celso Antonio Bandeira de Mello. Curso de Direito Administrativo. 26a ed. São Paulo: Malheiros Editores, 2009.

MILARÉ, Édis. Direito do ambiente: a gestão ambiental em foco, doutrina, jurisprudência, glossário.. São Paulo: Revista dos Tribunais.

NASCIMENTO, L. F.; LEMOS A. D. C., MELLO, M. C. A. Gestão socioambiental estratégica. Porto Alegre: Bookman, 2008.

OLIVEIRA, Danilo . Apontaentos sobre a Reforma Agrária no Brasil. Disponível em: <https://danilooliveira810.jusbrasil.com.br/artigos/411691413/apontamentos-sobre-a-reforma-agraria-no-brasil>. Acesso em 07/10/2017.

PEREIRA, Samuel Ricardo. O Direito de Propriedade e a Desapropriação. Disponível em: $<$ http://lyceumonline.usf.edu.br/salavirtual/documentos/1459.pdf>. Acesso em 07/10/2017.

REVISTA DOS TRIBUNAIS, 1988, p. 55-56 apud MORAES, 2002, p. 33. 